\title{
College English Listening Teaching Design Based on Computer Multimedia Teaching Platform
}

\author{
https://doi.org/10.3991/ijet.v13i04.8473 \\ Yue Dai \\ Beihua University, China \\ 7119069 e qq.com
}

\begin{abstract}
In order to simulate students' enthusiasm in English listening and to improve teachers' teaching efficiency, application of computer multimedia technology in English listening teaching has been wildly used. The purpose of this paper is to study the practical application of multimedia technology in English listening teaching. This study also also aims to improve the cognition of multimedia-assisted technology by exploring actual teaching cases. It will eliminate existing misunderstanding of assisting English listening teaching and improve the teaching effect of English listening. In this study we first elaborated the theoretical basis of computer-assisted English listening teaching, and then clarified the teaching requirements of multimedia-assisted English listening teaching through questionnaires. Finally, the effect of computer-assisted multimedia was evaluated through teaching comparative experiments. This study has important guiding significance in promoting diversified development of college English listening teaching and in developing students' English listening ability and improving teachers' teaching skills.
\end{abstract}

Keywords-computer multimedia technology; listening teaching; questionnaire; teaching comparison

\section{Introduction}

The aim of English learning is to develop students' comprehensive ability in English, it mainly includes two kinds of abilities, namely oral English and written English. Listening, speaking, reading, writing and translating are reflections of five kinds of English abilities, of which listening and speaking abilities are the main reflections of a student's English proficiency. According to the statistics of linguists and language practice, the five skills in English accounting for listening-45\%, speaking-30\%, reading- $16 \%$ and writing\&translating- $9 \%$, respectively [1]. It can be seen from the data that listening plays a dominant role in English language teaching. Therefore, improving English listening ability of college students is the key in improving their overall English proficiency. With the rapid development of network and computer software technology, the development of information technology in English education has become a general trend. Teaching and learning of computer multimedia and soft- 
ware are driving the reform of listening teaching methods, listening teaching ideas and listening teaching contents [2].

Early in 2000, foreign scholars had investigated the level of foreign language listening learning under computer-based multimedia environment (CBME). Survey shows that computer multimedia can provide learners with fast and effective information dissemination and input, which can help learners understand information by providing guidance and timely monitoring and feedback [3]. In recent years, with the in-depth application of computer multimedia technology in English teaching, domestic scholars have also conducted research on computer multimedia in English listening [4]. Some scholars pointed out the "three steps" of the traditional listening teaching courses: playing the listening materials, checking the answers and repeating the recorded materials, this pattern has a poor effect on improving students' English listening ability; Some scholars have concluded that the audio-video combination teaching materials can stimulate the senses more directly to improve memory through combining sounds and images; and other scholars also concluded from the educational psychology point of view that students obtain $15 \%$ of their knowledges through listening, $25 \%$ knowledges from vision, and the combination of these two can increase knowledge acceptance level up to 65\% [5]. Although there are great achievements in the research of computer-assisted technology and listening teaching within our country, however, there are few teaching-case studies conduct argument from a comprehensive perspective to explore practical application of computer multimedia technologies in English listening teaching [6].

In this paper, the theoretical basis, principle and design theory of computer-assisted English teaching are comprehensively analyzed. The questionnaire survey is used to qualitatively study the demand of listening teaching, master the current situation of English listening teaching and improve the recognition of multimedia-assisted technology. Finally, through the actual teaching cases and statistics this paper analyzes the students' listening teaching test data, and draws research conclusions. This article has an important guiding role in improving the cognition of computer-assisted listening teaching and promoting the application of computer multimedia in English listening teaching.

\section{The theoretical basis of computer multimedia-assisted foreign language listening teaching}

\subsection{The theoretical basis of computer multimedia-assisted foreign language listening teaching}

Constructivism theory. The multimedia English listening teaching is in accordance with the constructivism learning environment. The constructivism theory considers the learning process as the construction of knowledges. Students cannot obtain knowledge directly from the teacher but by the assistance of teachers or computer technologies under certain teaching environment to complete their mastering of learning materials. 
Constructivism emphasizes student-centered thinking that students are the main body of cognition and the active constructor of knowledge and meaning. It emphasizes that learning is the result of the internal psychological interaction between the external environment and the cognitive subject, and proposes the cognitive process of construction from assimilation to conformation, as well as the cognition developing process from balance to imbalance and to a new balance; it also emphasizes the important role of learning environment in forming the construction of meaning [7].

Krashen's Second Language Acquisition Theory. For the second language learning, Krashen had proposed the "Input hypothesis" theory. The theory holds that teachers should provide enough language learning input for students and create an easy learning environment for students to complete their foreign language learning in a relaxed environment. At the same time Krashen's second language acquisition theory thinks that the two key factors of language learning are the appropriate language input and moderate emotional filtering. Based on Krashen's "Input hypothesis" theory, the computer-assisted multimedia learning style can provide students with a multi-media teaching style combining images, sounds, animations and texts, which can trigger students' interest in learning, and improve the efficiency of listening teaching [8].

\subsection{Principles and design of multimedia computer-assisted foreign language listening teaching}

Teaching principles. To apply computer multimedia technology into foreign language teaching and form a corresponding teaching style, there are certain principles one needs to follow. By summing up the application experiences, following principles are determined:

Learner-centered principle, let the learners give full play to their initiatives by conducting self-expression planning, self-organizing, self-evaluating under multimedia teaching style, teachers and teaching-assisting tools only provide guidance and assistance in the process [9].

Optimality principle, multimedia teaching is a diversified teaching style. In order to achieve the optimal effect, we need to choose different means of presentation, structural arrangement, role collocation and teaching method based on the requirements of the teaching materials to achieve the best teaching effect based on the optimality principle.

Interactive principle, the main characteristic of computer-assisted teaching style is to emphasize the equal relationship between teachers and students, that is to transfer from the traditional teacher-centered teaching style, to the student-centered teaching style. In this style, students interact with each other, or communicate with teachers to find and discuss common problems in the learning process [10].

Teaching design. Computer-assisted multimedia teaching has been widely used in college English teaching. However, since foreign language teachers didn't do much design work in multimedia teaching, instead they just simply using PPT or web pages to present the knowledge from the text books, thus leading to a poor teaching effect [11]. The teaching design is a scientific optimization method to use the systematic method to analyze, organize, coordinate the various elements of the teaching system, 
conduct overall design of the teaching process to achieve optimization. Below we introduce two multimedia teaching design cases:

Figure 1 shows the design of a slide show in teaching the University experience English comprehensive tutorial II, unit 1, topic Famous Universities:

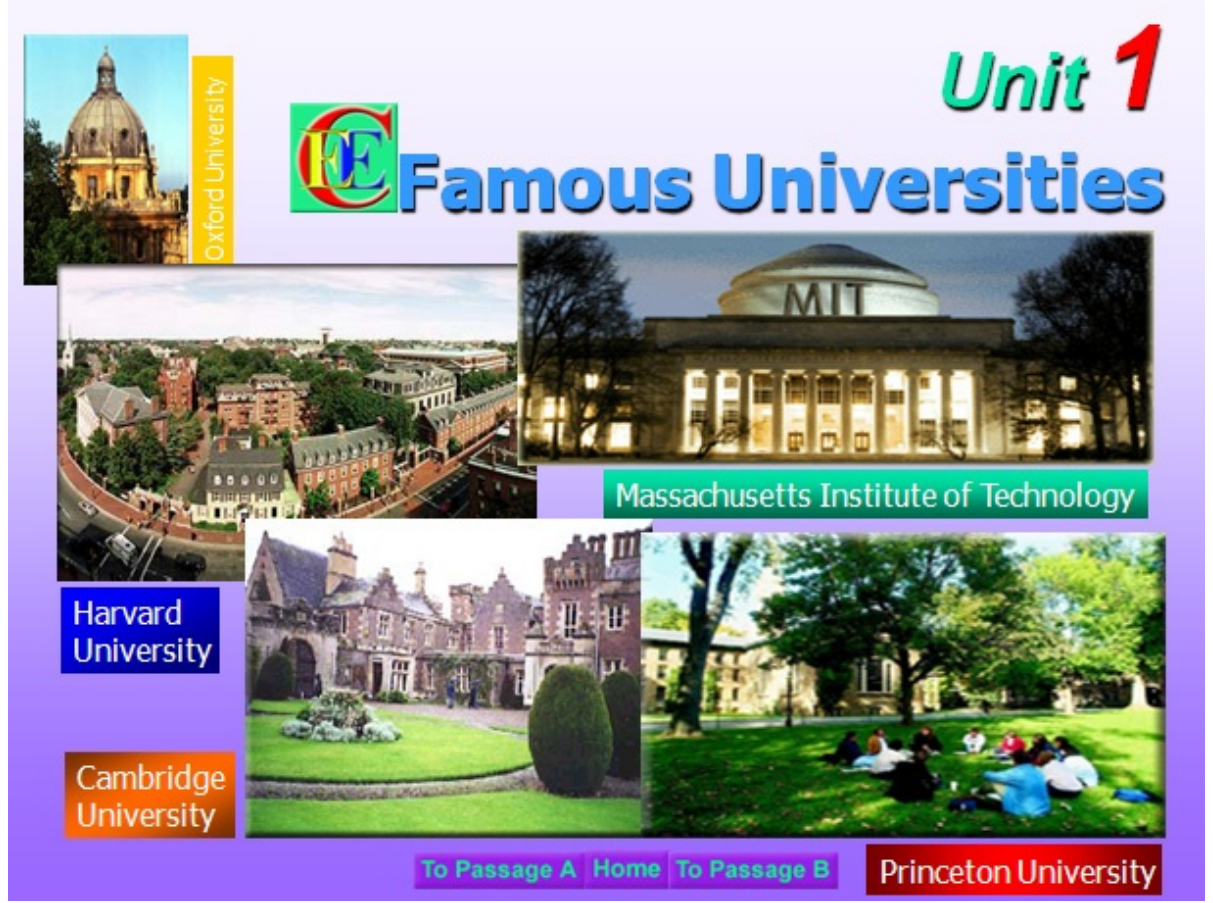

Fig. 1. World famous universities introduction

The slide show integrates sounds and images through videos, students can play the universities' introduction materials by clicking images on the slides, and complete the briefings of their chosen universities according to the video contents.

Figure 2 shows Bill Gates' student instruction speech excerpt which is selected by an English teacher, first, by clicking the play button, the slide enables students to complete a listening practice, then displays the listening content, by adding notes to key words, it helps students improving listening comprehension of the whole article. 


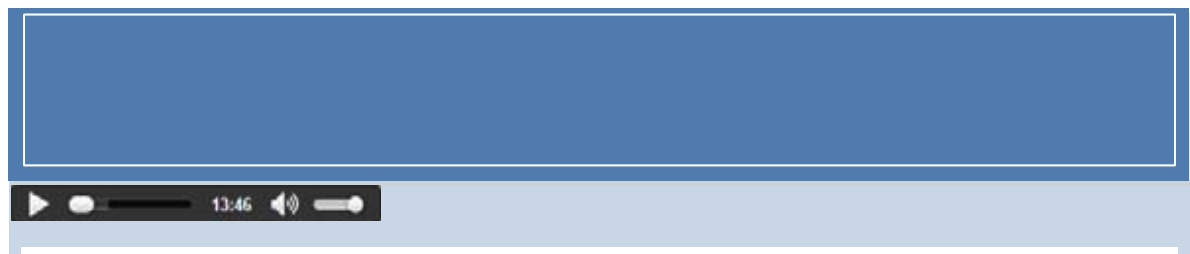

My Advice to Students: Education Counts

(1)) My basic advice is simple and heartfelt: Get the best education you can. Take advantage of high school and college. Learn how to learn.

(1) It's true that I dropped out of college to startMicrosoft, but I was at Harvard for three years before dropping out_-and I'd love to have the time to go back. As I've said before, nobody should drop out of college unless they believe they face the opportunity of a lifetime. And even then they should reconsider.

Fig. 2. Listening teaching case

Different multimedia listening teaching design must follow the design principles and based on the full analysis of teaching requirement and understanding of the student' listening abilities.

\section{Requirement analysis of computer multimedia-assisted foreign language listening teaching}

With the coming of information era, the multimedia-based and network-assisted foreign language teaching has become a trend which brings new styles to the foreign language teaching, optimizing classroom teaching and improving the quality of foreign language teaching [12].

\subsection{Requirement analysis survey design}

What is college students' attitude toward the computer multimedia-assisted foreign language listening teaching? What's the effect of using multimedia in classroom teaching? What are the disadvantages of current multimedia listening teaching? To better satisfy the requirement of multimedia listening teaching, this study uses questionnaire survey to conduct investigation of above issues [13].

The objects of the questionnaires are students from first grade to fourth grade with different foreign language levels in a college of the country, 320 questionnaires were sent out and 318 valid questionnaires were collected. 


\subsection{Questionnaire statistics and analysis}

Table 1. Table1 Students' understanding of computer-assisted multimedia teaching

\begin{tabular}{|c|c|c|c|c|c|}
\hline $\begin{array}{c}\text { I fully understand computer multimedia } \\
\text { assisted foreign language teaching }\end{array}$ & $\begin{array}{c}\text { Totally } \\
\text { agree }\end{array}$ & Agree & Not sure & Disagree & $\begin{array}{c}\text { strongly } \\
\text { disagree }\end{array}$ \\
\hline Answer Number & 0 & 18 & 94 & 179 & 27 \\
\hline Percentage & $0 \%$ & $5.7 \%$ & $29.5 \%$ & $56.2 \%$ & $8.5 \%$ \\
\hline
\end{tabular}

As can be seen from Table 1, students' degree of understanding of multimediaassisted teaching is very low, only $5.7 \%$ of students know about multimedia-assisted teaching. It shows that the college students' cognition level of computer multimedia popularization and the scientific cognition in our country are still at a low level.

Table 2. Students' viewpoints on computer multimedia-assisted foreign language teaching

\begin{tabular}{|c|c|c|c|c|c|}
\hline $\begin{array}{c}\text { Computer multimedia assisted foreign lan- } \\
\text { guage teaching is very helpful to my English } \\
\text { listening comprehension }\end{array}$ & $\begin{array}{c}\text { Totally } \\
\text { agree }\end{array}$ & Agree & $\begin{array}{c}\text { Not } \\
\text { sure }\end{array}$ & Disagree & $\begin{array}{c}\text { strongly } \\
\text { disagree }\end{array}$ \\
\hline Answer Number & 79 & 198 & 32 & 4 & 5 \\
\hline Percentage & $24.8 \%$ & $62.3 \%$ & $10.1 \%$ & $1.3 \%$ & $1.6 \%$ \\
\hline
\end{tabular}

As can be seen from the data in Table 2, there is a different level of recognition of computer-assisted multimedia teaching. Students have a keen interest in computer multimedia-assisted English listening teaching, 87.1\% of students agree that this teaching method is conducive in improving the level of English listening.

Table 3. Students' attitude towards traditional listening teaching methods

\begin{tabular}{|c|c|c|c|c|c|}
\hline $\begin{array}{c}\text { Traditional teaching of listening can no } \\
\text { longer meet the teaching needs }\end{array}$ & $\begin{array}{c}\text { Totally } \\
\text { agree }\end{array}$ & Agree & Not sure & Disagree & $\begin{array}{c}\text { strongly } \\
\text { disagree }\end{array}$ \\
\hline Answer Number & 32 & 27 & 35 & 123 & 98 \\
\hline Percentage & $10.1 \%$ & $8.5 \%$ & $11.0 \%$ & $39.6 \%$ & $30.8 \%$ \\
\hline
\end{tabular}

We can know from Table 3 that most students still think the traditional English listening teaching mode should be reserved. Their main concern is that under the multimedia teaching style, the communication between students and teachers will be reduced and teachers' evaluation and feedback of students will not be achieved [14]. Therefore, when college English teachers are carrying out multimedia-assisted listening teaching, they should scientifically design the teaching content and reasonably arrange human-computer interaction time and human-human interaction time, also they should make full use of multimedia technology as videos and images to increase students' interest in learning and improve the teachers' learning participation [15-25] as well.

Calculate the reasons why students think their listening ability level is not high, the results are shown in Table 4. 
Table 4. The reason for low level of students' listening ability

\begin{tabular}{|l|c|c|c|c|c|}
\hline & Totally agree & Agree & Not sure & Disagree & strongly disagree \\
\hline Less training time & 31 & 85 & 56 & 79 & 67 \\
\hline Percentage & $9.8 \%$ & $26.7 \%$ & $17.6 \%$ & $24.8 \%$ & $21.1 \%$ \\
\hline Improper teaching methods & 56 & 85 & 79 & 67 & 31 \\
\hline Percentage & $17.6 \%$ & $26.7 \%$ & $24.8 \%$ & $21.1 \%$ & $9.8 \%$ \\
\hline Hearing material is backward & 79 & 85 & 61 & 57 & 36 \\
\hline Percentage & $24.8 \%$ & $26.7 \%$ & $19.2 \%$ & $17.9 \%$ & $11.3 \%$ \\
\hline Non real environment & 79 & 85 & 69 & 54 & 31 \\
\hline Percentage & $24.8 \%$ & $26.7 \%$ & $21.7 \%$ & $17 \%$ & $9.8 \%$ \\
\hline
\end{tabular}

From Table 4, we can see that the listening materials were out-of-date, and the lack of real language environment are the main reasons the students think of causing their low level of listening ability. Therefore, teachers should update the listening material resources in a timely manner, enrich teaching materials through images, videos, audio and other means to stimulate the students' interest in learning; in addition, teachers should pay attention to classroom communication to provide students with oral English practicing opportunities thus indirectly cultivate their English listening abilities.

\section{Practice and result analysis of computer multimedia-assisted English listening teaching}

\subsection{Experiment design of experimental listening teaching}

To test the application effect of the computer multimedia-assisted method in college English listening, this paper selects two parallel classes of English majors in a university to conduct a teaching experiment in one semester. The results are calculated by two test contents, scores before and after the test are calculated respectively.

Goal of experimental teaching. We are aiming to solve the following two goals by this experiment:

1. Quantitative evaluation of the impact of computer multimedia-assisted teaching on English listening.

2. Optimal computer multimedia-assisted English listening teaching style exploration through analysis of the teaching practice results.

Test materials. Test Material 1: From the Latest College English Test Band Four (CET-4), randomly select several traditional English listening test questions, such as: Statement dictation, Statement comprehension, Conversation comprehension, Passage comprehension and Spot dictation, all five parts. All questions are objective multiplechoice questions, there are 10 questions in each part, and 2 points for each question, all 100 points, test time is 30 minutes. 
Test Material 2: The test content is a Family Album U.S.A video clip, which requires students to answer open questions that are designed by the teachers according to the video clip. The total points are 100.

Experimental process. The teaching cycle is 16 weeks, 1 hour in every week for the listening teaching. It requires 35 students from the experimental class to take a multimedia listening practice every two week. In the control class, 33 students are required to take 2 hours classroom listening teaching practice every two weeks, traditional recording materials listening-writing and teacher explanation style is taken in this class.

\subsection{Result Analysis of experimental listening teaching}

Experimental results analysis of test material 1. It can be seen from Table 5 and Table 6 that after a semester of English listening teaching, the test scores of the experimental group increased by $6.9 \%$ compared with the control group only increased by $3.5 \%$ in the case of the equal pre-test scores, which verified that computer multimedia-assisted technology improved more scores than the traditional listening teaching styles.

Table 5. Traditional listening teaching test average score comparison

\begin{tabular}{|l|c|c|c|}
\hline \multirow{2}{*}{\multicolumn{1}{c|}{ Group type }} & Pretesting & Aftertest & \multirow{2}{*}{ Percentage increase } \\
\cline { 2 - 3 } & Mean value & Mean value & 6.9 \\
\hline Test group & 62.5 & 66.8 & 3.5 \\
\hline Control group & 62.4 & 64.6 & 3.6 \\
\hline
\end{tabular}

Table 6. Traditional listening teaching test each content score comparison

\begin{tabular}{|c|l|c|c|c|}
\hline \multicolumn{1}{|c|}{ Croup type } & \multicolumn{1}{|c|}{ Content } & Value & Pretesting & Aftertest \\
\hline \multirow{4}{*}{ Test group } & Statement dictation & 20 & 11.4 & 12.0 \\
\cline { 2 - 5 } & Statement comprehension & 20 & 13.8 & 14.9 \\
\cline { 2 - 5 } & Conversation comprehension & 20 & 12.3 & 13.3 \\
\cline { 2 - 5 } & Passage comprehension & 20 & 11.1 & 12.3 \\
\cline { 2 - 5 } & Spot dictation & 100 & 11.1 & 12.3 \\
\cline { 2 - 5 } & Total score & 20 & 62.5 & 66.8 \\
\hline \multirow{3}{*}{ Control group } & Statement dictation & 20 & 11.5 & 11.7 \\
\cline { 2 - 5 } & Statement comprehension & 20 & 13.6 & 14.4 \\
\cline { 2 - 5 } & Conversation comprehension & 20 & 11.1 & 12.5 \\
\cline { 2 - 5 } & Passage comprehension & 100 & 14 & 14.3 \\
\cline { 2 - 5 } & Spot dictation & 62.4 & 64.6 \\
\hline
\end{tabular}

Experimental results analysis of test material 2. It can be seen from Table 7 that the average score difference in the pre-test is not quite obvious. However, in the posttest, the scores of the two classes have changed significantly. The score of the experimental class has increased by $9.2 \%$, compared with only $5.8 \%$ of the control class. 
This shows that computer-assisted learning has a better overall listening comprehension level for students than the traditional listening teaching.

Table 7. Video clips test comparison

\begin{tabular}{|l|c|c|c|c|}
\hline & Number & Pretesting & Aftertest & Percentage increase \\
\hline Test group & 35 & 68.8 & 72.8 & 5.8 \\
\hline Control group & 33 & 70.5 & 77.1 & 9.2 \\
\hline
\end{tabular}

In addition, by analyzing the score of each single test in Table 6 , it is found that the score of each single item is not significantly different; however, the video listening scores in Table 7 are quite different. Through the analysis, it is considered that the comprehensive of listening content of test material 1 is in lack of certain context, and the computer multimedia teaching environment didn't obviously affect it. In other words, to improve listening teaching effect of computer multimedia, the choice of listening material is the key in a successful multimedia classroom.

\section{Conclusion}

Through references review, we find that within our country, there is a lack of comprehensive analysis of computer multimedia-assisted language teaching in college English listening teaching application, and there is not much studies in its actual teaching application either. This paper summarizes the theoretical basis, design principles and design concepts of computer multimedia technology in English listening teaching, designs teaching practice cases based on the teaching requirements, and draws the following conclusions and tips through the test results:

1. Through the comparative analysis of pre-test and post-test scores, it shows that multimedia-assisted listening teaching has a better teaching effect than traditional listening teaching.

2. The design of multimedia classroom should be improved during the implementation of computer multimedia listening teaching. The selection of listening materials is the key to provide good effect of multimedia listening teaching style.

\section{References}

[1] Meng, Q., Meng, Q. (2017). A study on cultivating college students' oral English ability based on computer assisted language learning environment. Boletin Tecnico/technical Bulletin, 55(4), 80-85.

[2] Yang, L.L. (2013). Students' English comprehensive ability based on Anglo- American literature. International Journal of Technology Management, 88-90.

[3] Johnson, C.I., Mayer, R.E. (2010). Applying the self-explanation principle to multimedia learning in a computer-based game-like environment. Computers in Human Behavior, 26(6), 1246-1252. https://doi.org/10.1016/j.chb.2010.03.025 
[4] Marín, R., Sanz, P.J., Coltell, O., Inesta, J.M., Barber, F., Corella, D. (1997). Studentteacher communication directed to computer-based learning environments. Displays, 17(3-4), 167-178. DOI: /10.1016/s0141-9382(96)01033-5 https://doi.org/10.1016/S01419382(96)01033-5

[5] Ni, D. (2017). Design and research on English listening teaching assisted by computer multimedia. International Journal of Emerging Technologies in Learning, 12(1), 32. https://doi.org/10.3991/ijet.v12i01.6053

[6] Guo, T., Jia, Q. (2016). Research on the impact of multimedia computer-based English teaching in high school. International Journal of Emerging Technologies in Learning, 11(8), 33. https://doi.org/10.3991/ijet.v11i08.6042

[7] Xia, K. (2015). Exploration on the scaffolding instruction mode in higher vocational oral English teaching guided by the constructivism theory. Bioresource Technology, 191(1), 146-156.

[8] Tricomi, E.T. (1986). Krashen's second-language acquisition theory and the teaching of edited American English. Journal of Basic Writing, 5(2), 59-69.

[9] Fischer, R. (1996). Interactive video listening comprehension in foreign language instruction: development and evaluation. Biochemical Journal, 374(5), 739-745.

[10] Chen, H.Y., Liu, K.Y. (2006). Exploring multimedia correlation and synchronization for web-based language learning. IEEE Multimedia, 13(4), 50-61. https://doi.org/10.1109/ MMUL.2006.80

[11] Shaw, M.J., Cass, O.W., Sales, G.L., Tomshine, P.A., Reynolds, J.F. (1995). Computer assisted multimedia education of patients for colonoscopy. Gastrointestinal Endoscopy, 41(4), 330-330. https://doi.org/10.1016/S0016-5107(05)80175-0

[12] Kohlmeier, L., Mendez, M., Mcduffie, J., Miller, M. (1997). Computer-assisted selfinterviewing: a multimedia approach to dietary assessment. American Journal of Clinical Nutrition, 65(4 Suppl), 1275S. https://doi.org/10.1093/ajcn/65.4.1275S

[13] Shi, S. (2016). Computer English teaching model based on multimedia platform. International Journal of Emerging Technologies in Learning, 11(8), 59. https://doi.org/10.3991/ ijet.v11i08.6050

[14] Mohsen, M.A. (2016). The use of help options in multimedia listening environments to aid language learning: a review. British Journal of Educational Technology, 47(6), 1232-1242. https://doi.org/10.1111/bjet.12305

[15] Chiu, Y.H. (2013). Computer-assisted second language vocabulary instruction: a metaanalysis. British Journal of Educational Technology, 44(2), E52-E56. https://doi.org/10.1111/j.1467-8535.2012.01342.x

[16] Ehrlich, M., Shields, T. J., Almaev, T. and Amer, M. R. (2016). Facial Attributes Classifica-tion Using Multi-Task Representation Learning. In Proceedings of the IEEE Conference on Computer Vision and Pattern Recognition Workshops 47-55.

[17] Buczak, A. L. and Guven, E. (2016). A survey of data mining and machine learning methods for cyber security intrusion detection. IEEE Communications Surveys \& Tutorials, 18(2), 1153-1176. https://doi.org/10.1109/COMST.2015.2494502

[18] Kolosnjaji, B., Zarras, A., Webster, G., \& Eckert, C. (2016). Deep Learning for Classification of Malware System Call Sequences. In Australasian Joint Conference on Artificial Intelligence, 137-149. Springer International Publishing.

[19] Wang, W., Zhu, M., Zeng, X., Ye, X. and Sheng, Y. (2017). Malware Traffic Classification Using Convolutional Neural Network for Representation Learning. In Information Network-ing (ICOIN), 2017 International Conference on, 712-717. https://doi.org/10.1109/ICOIN.2017.7899588 
[20] Trentin, G. (2006). The Xanadu project: training faculty in the use of information and com-munication technology for university teaching. Journal of Computer Assisted Learning, 22(3), 182-196. https://doi.org/10.1111/j.1365-2729.2006.00168.x

[21] Colbert, M., Voglimacci, C., Finkelstein, F. (1995). Live, audio-visual communication systems for distance learning: experience, heuristics, and isdn. Behaviour \& Information Tech-nology, 14(5), 267-288. https://doi.org/10.1080/01449299508914647

[22] Castro, M., Lopez-Rey, A., Perez-Molina, C.M., Colmenar, A. (2001). Examples of distance learning projects in the European community. IEEE Transactions on Education, 44(4), 406-411. https://doi.org/10.1109/13.965791

[23] Zhang, E.W., Zhang W.M., Jin, C.X. (2018). SPOC-based Flipped Classroom of College English: Construction of an Effective Learning Model. International Journal of Emerging Technologies in Learning, 14, 37-47. https://doi.org/10.3991/ijet.v13i01.7513

[24] Phuapan, P., Viriyavejakul, C., Pimdeepp, P. (2016). An Analysis of Digital Literacy Skills among Thai University Seniors, International Journal of Emerging Technologies in Learn-ing, 11, 24-31. https://doi.org/10.3991/ijet.v11i03.5301

[25] Liu, Q.H. (2015). The teaching design should deal with the relationship between the learning content, the learning task and the students - the two courses of the single chip computer pro-gramming and realization course. Journal of Xingtai Polytechnic College, 5, 1-3.

\section{$7 \quad$ Author}

Yue Dai received the B.A. degree in English language teaching from Ji Lin Normal University, Siping, China, in 2002, and the M.A. degree in foreign and applied linguistics from Beihua University in 2008. She is currently working in Beihua University. Her research interests include language teaching, translation studies and practice.

Article submitted 20 February 2018. Final acceptance 25 March 2018. Final version published as submitted by the author. 